\title{
An ADH toolbox for raspberry ketone production from natural resources via a biocatalytic cascade
}

\author{
Aileen Becker ${ }^{1} \cdot$ Dominique Böttcher $^{1} \cdot$ Werner Katzer ${ }^{2} \cdot$ Karsten Siems $^{2} \cdot$ Lutz Müller-Kuhrt $^{2} \cdot$ Uwe T. Bornscheuer $^{1}$ (D)
}

Received: 10 March 2021 / Revised: 27 April 2021 / Accepted: 3 May 2021 / Published online: 14 May 2021

(C) The Author(s) 2021

\begin{abstract}
Raspberry ketone is a widely used flavor compound in food and cosmetic industry. Several processes for its biocatalytic production have already been described, but either with the use of genetically modified organisms (GMOs) or incomplete conversion of the variety of precursors that are available in nature. Such natural precursors are rhododendrol glycosides with different proportions of $(R)$ - and $(S)$-rhododendrol depending on the origin. After hydrolysis of these rhododendrol glycosides, the formed rhododendrol enantiomers have to be oxidized to obtain the final product raspberry ketone. To be able to achieve a high conversion with different starting material, we assembled an alcohol dehydrogenase toolbox that can be accessed depending on the optical purity of the intermediate rhododendrol. This is demonstrated by converting racemic rhododendrol using a combination of $(R)$ - and $(S)$-selective alcohol dehydrogenases together with a universal cofactor recycling system. Furthermore, we conducted a biocatalytic cascade reaction starting from naturally derived rhododendrol glycosides by the use of a glucosidase and an alcohol dehydrogenase to produce raspberry ketone in high yield.
\end{abstract}

\section{Key points}

- LB-ADH, LK-ADH and LS-ADH oxidize (R)-rhododendrol

- RR-ADH and ADH1E oxidize (S)-rhododendrol

- Raspberry ketone production via glucosidase and alcohol dehydrogenases from a toolbox

Keywords Raspberry ketone $\cdot$ Biocatalysis $\cdot$ Enzymatic cascade $\cdot$ Natural products $\cdot$ Alcohol dehydrogenase toolbox

\section{Introduction}

Raspberry ketone (4-(4-hydroxyphenyl)-butan-2-one) is of high economical relevance (Wang et al. 2019) due to its characteristic scent and low odor threshold (Larsen and Poll 1990). The aroma compound is widely applied as flavoring agent in food industry for products like sweets, yoghurts, or soft drinks (Deifel 1989; Beekwilder et al. 2007; Wang et al. 2019; Milke et al. 2020). In addition, raspberry ketone is utilized as an attractant in insect baits (Perez 1983; Metcalf et al. 1983;

Uwe T. Bornscheuer

uwe.bornscheuer@uni-greifswald.de

1 Department of Biotechnology and Enzyme Catalysis, Institute of Biochemistry, University of Greifswald, Greifswald, Germany

2 AnalytiCon Discovery GmbH, Potsdam, Germany
Deifel 1989) and as a component in perfumes (Dumont et al. 1996; Farwick et al. 2019), whereas further applications in cosmetic industry, e.g., as skin whitening or hair growth inducing agent, remain controversial (Harada et al. 2008; Kim et al. 2016). Other publications promote dose-dependent health benefits with regard to an anti-obese effect (Morimoto et al. 2005; Park 2015; Tsai et al. 2017; Zhao et al. 2019; Mir et al. 2019) or suggest medical applications due to its antioxidant and anti-inflammatory potential (Parmar and Tripathi 1991; Khan et al. 2018; Fouad et al. 2019; Mohamed et al. 2020; Hamdy et al. 2020).

So far, the chemical-synthetic production of raspberry ketone is dominating the market. However, increasing consumer awareness is demanding for a naturally derived product, especially in food and cosmetic industry (Milke et al. 2020; Malik and Rawat 2021). Natural production methods do not only include the direct isolation from natural sources, but also the enzymatic or microbial bioconversion of natural precursors, 
according to EU regulations (Kosjek et al. 2003; European Parliament 2008; Schloesser and Lambert 2018; Milke et al. 2020).

As its natural occurrence in raspberries and other fruits like peaches or grapes is very low-only $1-4 \mathrm{mg} / \mathrm{kg}$ raspberries (Larsen et al. 1991; Wang et al. 2019; Malik and Rawat 2021) - a direct isolation proves to be economically inefficient (Beekwilder et al. 2007; Wang et al. 2019). However, raspberry ketone precursors can be found in vegetables like rhubarb (Deifel 1989) or in the bark of plants like birch (Betula spp. (Santamour and Vettel 1978; Santamour and Lundgren 1997; Liimatainen et al. 2012)), rhododendron (Rhododendron spp. (Thieme et al. 1969; Parmar and Tripathi 1991)), or yews (Taxus spp. (Parmar and Tripathi 1991; Fronza et al. 1999)) in significantly larger quantities, e.g., $24.5 \mathrm{~g} / \mathrm{kg}$ in dried inner bark of Betula pendula (Liimatainen et al. 2012). The most abundant natural raspberry ketone precursor is the corresponding alcohol rhododendrol (4-(4-hydroxyphenyl)-butan-2-ol). Rhododendrol occurs as aglycone moiety of different glycosides with varying rhododendrol stereoisomers such as (epi)rhododendrin, apiosyl(epi)rhododendrin, or arabinosyl(epi)rhododendrin (Šmite et al. 1993; Santamour and Lundgren 1997). Even among the same genus, the contents of $(R)$ - and $(S)$ rhododendrol can vary significantly: for example, in Betula nana, the $(R)$-enantiomer dominates with $97 \%$, whereas in Betula fruticosa, both enantiomers occur in nearly equal amounts, and in Betula saposhnikovii, glycosides with the $(S)$-enantiomer can be found predominantly (Falconnier et al. 1999).

In literature, different routes for the natural production of raspberry ketone are stated: on the one hand, this can be achieved by heterologous pathways in microorganisms incorporated via metabolic engineering. Approaches with engineered microorganisms like E. coli, S. cerevisiae, or C. glutamicum yielded product titers between 5 and $9.89 \mathrm{~g} / \mathrm{l}$ raspberry ketone either starting from expensive $p$-coumaric acid (Beekwilder et al. 2007; Lee et al. 2016; Wang et al. 2019; Milke et al. 2020; Paulino 2021), lower-priced tyrosine (Farwick et al. 2019), 4-hydroxybenzylidene acetone (Yang et al. 2021), or fatty acids as alternative low-cost feedstock (Chang and Liu 2021). Furthermore, the de novo production of raspberry ketone was achieved by genetically modified E. coli or C. glutamicum strains that produce tyrosine by themselves yielding $19 \mathrm{mg} / \mathrm{l}$ (Cankar et al. 2019) or even up to $780 \mathrm{mg} / 1$ raspberry ketone (Schloesser and Lambert 2018). A drawback of these previously described methods is that "foods that $[\ldots]$ contain ingredients produced from GMOs" have to be labeled as, e.g., "genetically modified" according to EU law (European Parliament 2003; Deckers et al. 2020), which might be deterrent to consumers.

On the other hand, strategies utilizing precursors like rhododendrol glycosides isolated from Betulaceae or other plants as starting material are described. The conversion of rhododendrol glycosides isolated from $B$. alba was attained by a commercial $\beta$-glucosidase and Candida boidinii cells providing alcohol dehydrogenase (ADH) activity with a maximum yield of $44.5 \%$ (Dumont et al. 1996). A similar approach with yeast cells comprising both $\beta$-glucosidase and ADH activity resulted in $82.1 \%$ raspberry ketone (Falconnier et al. 1999). Additionally, the kinetic resolution of racemic rhododendrol was demonstrated by using lyophilized cells of Rhodococcus spp. resulting in a conversion of 52 $\%$ (Kosjek et al. 2003). These procedures have in common that only one of the rhododendrol enantiomers is converted leaving space for improvement depending on the composition of the starting material.

With this work, we overcame the limitations of existing strategies starting from rhododendrol glycosides by providing an ADH toolbox implemented in a biocatalytic cascade (Fig. 1). This toolbox contains ADHs with different selectivities for $(R)$ - or $(S)$-rhododendrol and, additionally, a universal cofactor regeneration system, thus, enabling the conversion of both rhododendrol enantiomers from various starting materials isolated from natural resources to achieve a higher conversion.

\section{Materials and methods}

\section{Material}

The substrate (1:1 rhododendrol glycoside mixture of arabinosyl- and apiosylrhododendrin derived from Betula pendula) and intermediate (racemic rhododendrol, NP000438) were provided by AnalytiCon Discovery $\mathrm{GmbH}$ (Potsdam, DE). Raspberry ketone standard (68524) and commercial $\beta$-glucosidase from almonds (49290, 7.3 U/mg) were purchased from Sigma-Aldrich (St. Louis, USA). Chemically competent E. coli BL21(DE3) were obtained from New England Biolabs GmbH (Frankfurt am Main, DE) and E. coli C43(DE3) from Sigma-Aldrich (St. Louis, USA). ADH from Equus caballus (ADH1E, 142 27 U/1) codonoptimized and subcloned in pET-28a (GenBank: MW808988) and Streptococcus mutans NAD(P)H oxidase variant 193R194H (SmNOX, $28.8 \mathrm{U} / \mathrm{ml}$ ) by Petschacher et al. 2014 codon-optimized and subcloned in pET-28a (GenBank: MW808989) were ordered at BioCat $\mathrm{GmbH}$ (Heidelberg, DE). Moreover, the following ADHs were used in this study: ADH from Lactobacillus brevis (LB-ADH, 17.2 $\pm 0.1 \mathrm{U} / \mathrm{ml}$, GenBank: MW808993) subcloned in pEG180 (originally provided by Prof. W. Kroutil, University of Graz, Austria), Lactobacillus kefir (LK-ADH, 30.1 $2.8 \mathrm{U} / \mathrm{ml}$, GenBank: MW808990) subcloned in pET-22b (originally provided by Prof. W. Hummel, University of Düsseldorf, Germany), Leifsonia sp. (LS-ADH, 90.3 \pm 5.7 U/1, GenBank: MW808992) subcloned in pEG50 (originally provided by 
Fig. 1 Reaction scheme for the natural production of raspberry ketone starting from naturally occurring rhododendrol glycosides. Rhododendrol glycosides are hydrolyzed by a glucosidase followed by the oxidation of the intermediates $(R)$ - and $(S)$-rhododendrol to raspberry ketone by an $\mathrm{ADH}$ toolbox and a universal cofactorregenerating oxidase SmNOX (Petschacher et al. 2014)

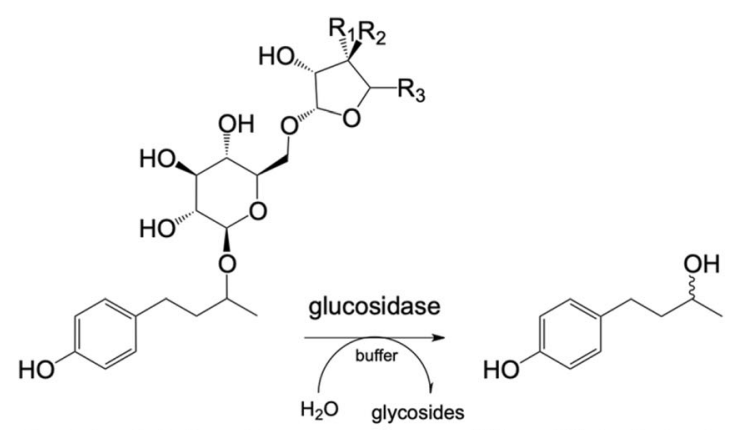

$(R)$ - or (S)-rhododendrol

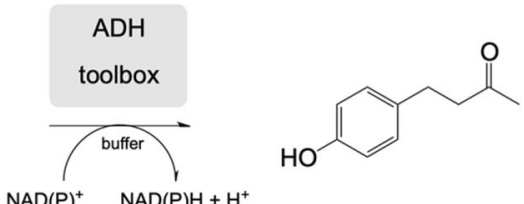

raspberry ketone
Prof. W. Kroutil, University of Graz, Austria), and Rhodococcus ruber (RR-ADH, 20.1 \pm 1.5 U/ml, GenBank: MW808991) subcloned in pKA1.

\section{Expression and determination of activity of the alcohol dehydrogenases}

All ADHs were expressed in E. coli C43(DE3) (LB-ADH (Sattler et al. 2014)) or E. coli BL21(DE3) (all other ADHs). In brief, $50 \mathrm{ml}$ (or $300 \mathrm{ml}$ ) terrific broth (TB) medium supplemented with $100 \mu \mathrm{g} / \mathrm{ml}$ ampicillin (LB-, LK-, LS-ADH) or $100 \mu \mathrm{g} / \mathrm{ml}$ chloramphenicol (RR-ADH) was inoculated with 1 $\%(\mathrm{v} / \mathrm{v})$ of the overnight culture, grown at $37^{\circ} \mathrm{C}$ and $180 \mathrm{rpm}$ until an $\mathrm{OD}_{600}$ of 0.8 (LB-ADH), 0.5 (LK-ADH), 0.6 (LS$\mathrm{ADH}$ ), or 0.3 (RR-ADH). Additionally, the media was supplemented with $1 \mathrm{mM} \mathrm{MgCl}$ (LB-ADH and LK-ADH) or $1 \mathrm{mM} \mathrm{ZnCl}_{2}$ (RR-ADH). Protein expression was induced by addition of $0.4 \mu \mathrm{M}$ anhydrotetracycline (LB-ADH), $1 \mathrm{mM}$ IPTG (LK-ADH), $0.4 \mathrm{mM}$ IPTG (LS-ADH), or $40 \mu \mathrm{M}$ IPTG (RR-ADH). The cells were grown for $22 \mathrm{~h}$ at $20{ }^{\circ} \mathrm{C}$ (LB-, LK-, and RR-ADH) or $37{ }^{\circ} \mathrm{C}$ (LS-ADH). ADH1E was expressed in $50 \mathrm{ml} \mathrm{TB}$ auto-induction medium supplemented with $50 \mu \mathrm{g} / \mathrm{ml}$ kanamycin, $2 \mathrm{mM} \mathrm{MgSO}_{4}, 0.2 \times$ trace elements, and inoculated with $1 \%$ overnight culture. Cells were grown at $37^{\circ} \mathrm{C}$ and $180 \mathrm{rpm}$ for $17 \mathrm{~h}$.

The cells were harvested by centrifugation $(10,000 \times g, 3$ min, $4{ }^{\circ} \mathrm{C}$ ), washed with $10 \mathrm{ml}$ of $25 \mathrm{mM}$ sodium phosphate buffer $\mathrm{pH} 8$, and disrupted via sonication (50\% power, 6x $30 \mathrm{~s}$ with 30 s breaks) with the SONOPULS HD 2070 (BANDELIN electronic GmbH \& Co. KG, Berlin, DE). The crude lysate, received after centrifugation at $10,000 \times \mathrm{g}$ and 4 ${ }^{\circ} \mathrm{C}$ for $30 \mathrm{~min}$, was used for further experiments.

Activity of the crude enzyme lysate was determined spectrophotometrically via a $\mathrm{NAD}(\mathrm{P}) \mathrm{H}$ assay at $25{ }^{\circ} \mathrm{C}$. For this purpose, $20 \mu \mathrm{l}$ enzyme lysate was mixed with $0.5 \mathrm{mM}$ $\mathrm{NAD}(\mathrm{P})^{+}, 39 \mathrm{mM}$ buffer, and $1 \mathrm{mM}$ racemic rhododendrol in acetonitrile (MeCN, $2.5 \% \mathrm{v} / \mathrm{v})$ in a total volume of $200 \mu \mathrm{l}$. $\mathrm{NADH}$ formation was quantified at $340 \mathrm{~nm}$ using the Infinite
M200 PRO microplate reader (Tecan Group, Männedorf, $\mathrm{CH})$. One unit of activity was defined as the amount of enzyme forming $1 \mu$ mol $\mathrm{NAD}(\mathrm{P}) \mathrm{H}$ per minute under assay conditions.

\section{Expression and determination of activity of the cofactor-recycling enzyme SmNOX}

SmNOX was expressed in E. coli BL21 (DE3). Fifty milliliter TB auto-induction medium supplemented with $50 \mu \mathrm{g} / \mathrm{ml}$ kanamycin was inoculated with $1 \%$ overnight culture, grown for $6 \mathrm{~h}$ at $37^{\circ} \mathrm{C}$ and $180 \mathrm{rpm}$, and, finally, cooled down to 20 ${ }^{\circ} \mathrm{C}$ for further growth overnight. Cells were harvested by centrifugation $\left(10,000 \times \mathrm{g}, 3 \mathrm{~min}, 4{ }^{\circ} \mathrm{C}\right)$, washed with $10 \mathrm{ml}$ $50 \mathrm{mM}$ CHES buffer $\mathrm{pH} 9$ and disrupted via sonication (50 $\%$ power, 4x 1 min with 1 min breaks) with the SONOPULS HD 2070 (BANDELIN electronic GmbH \& Co. KG, Berlin, $\mathrm{DE})$. The crude lysate, received after centrifugation at $10,000 \times g$ and $4{ }^{\circ} \mathrm{C}$ for $30 \mathrm{~min}$, was used for further experiments.

Activity was determined spectrophotometrically via a $\mathrm{NADH}$ assay at $25^{\circ} \mathrm{C}$. For this purpose, $20 \mu \mathrm{l}$ enzyme lysate was mixed with $45 \mathrm{mM}$ CHES buffer $\mathrm{pH} 9$ and $1 \mathrm{mM}$ NADH in a total volume of $200 \mu \mathrm{l}$. NADH consumption was quantified at $340 \mathrm{~nm}$ during $5 \mathrm{~min}$ using the Infinite M200 PRO microplate reader (Tecan Group, Männedorf, $\mathrm{CH}$ ). One unit of activity was defined as the amount of enzyme consuming $1 \mu \mathrm{mol}$ NADH per minute under assay conditions.

\section{Oxidation of rhododendrol by the alcohol dehydrogenases}

One millimolar racemic rhododendrol (added from a stock solution prepared in $\mathrm{MeCN}$, leading to a final concentration of $1 \% \mathrm{MeCN}$ in the reaction mixture) was oxidized in a buffered system by the addition of $200 \mu \mathrm{l}$ recombinantly expressed ADH lysate (RR-ADH, ADH1E, LB-ADH, LK$\mathrm{ADH}$, or $\mathrm{LS}-\mathrm{ADH}$ ) in a total reaction volume of $500 \mu \mathrm{l}$ in 
glass vials. One hundred micromolars of $\mathrm{NAD}(\mathrm{P})^{+}$were added and recycled by $0.6 \mathrm{U} / \mathrm{ml} \mathrm{SmNOX}$. The reactions were performed in triplicates either in $28 \mathrm{mM} \mathrm{CHES} \mathrm{buffer} \mathrm{pH} 9$ at $25^{\circ} \mathrm{C}$ (RR-ADH and LB-ADH), $28 \mathrm{mM} \mathrm{CHES} \mathrm{buffer} \mathrm{pH} 9$ at $40^{\circ} \mathrm{C}$ (LK-ADH), or $28 \mathrm{mM}$ glycine-NaOH buffer $\mathrm{pH} 10$ at $40^{\circ} \mathrm{C}$ (ADH1E and LS-ADH) at $1000 \mathrm{rpm}$ in a ThermoMixer C (Eppendorf AG, Hamburg, DE).

Conversion of both rhododendrol enantiomers was achieved by applying $100 \mu \mathrm{l}$ enzyme lysate of ADH1E and $\mathrm{LK}-\mathrm{ADH}$ each. The reaction with $1 \mathrm{mM}$ racemic rhododendrol in $\mathrm{MeCN}(1 \%), 50 \mu \mathrm{M} \mathrm{NAD}{ }^{+}, 50 \mu \mathrm{M}$ $\mathrm{NADP}^{+}$, and $0.6 \mathrm{U} / \mathrm{ml} \mathrm{SmNOX}$ was conducted in triplicates in $28 \mathrm{mM}$ glycine- $\mathrm{NaOH}$ buffer $\mathrm{pH} 10$ at $40^{\circ} \mathrm{C}$ and $1000 \mathrm{rpm}$ in a ThermoMixer C (Eppendorf AG, Hamburg, DE).

\section{Enzymatic hydrolysis of rhododendrol glycosides}

One to $10 \mathrm{mg} / \mathrm{ml}$ rhododendrol glycosides were hydrolyzed by 0.1 to $1 \mathrm{mg} / \mathrm{ml}$ ALM in glass vials and a reaction volume of $500 \mu \mathrm{l}$. The reaction took place in triplicates in $25 \mathrm{mM}$ sodium acetate buffer $\mathrm{pH} 5.5$ shaking at $40{ }^{\circ} \mathrm{C}$ and $1200 \mathrm{rpm}$ in a ThermoMixer C (Eppendorf AG, Hamburg, DE).

\section{Two-step biocatalytic cascade for raspberry ketone production}

One hundred fifty milligrams of the rhododendrol glycoside mix $(21.7 \mathrm{mM})$ and $15 \mathrm{mg}$ ALM $(7.4 \mu \mathrm{M})$ were stirred in $15 \mathrm{ml} 25 \mathrm{mM}$ sodium acetate buffer $\mathrm{pH} 5.5$ in a roundbottom flask at $40{ }^{\circ} \mathrm{C}$ for $24 \mathrm{~h}$. The reaction was cooled down to $25^{\circ} \mathrm{C}$ and diluted by a factor of 10 to a final volume of $150 \mathrm{ml}$ by adding the following reactants: $50 \mathrm{ml}$ LB-ADH lysate $(5.7 \mathrm{U} / \mathrm{ml}), 100 \mu \mathrm{M} \mathrm{NADP}^{+}, 0.6 \mathrm{U} / \mathrm{ml} \mathrm{SmNOX}$, and $55 \mathrm{mM}$ CHES buffer $\mathrm{pH} 9$. After $24 \mathrm{~h}$, the reaction mixture was extracted six times with $50 \mathrm{ml}$ ethyl acetate. The combined organic phases were evaporated to dryness and analyzed via GC and NMR.

\section{Analytics}

MS measurements were performed using an expression ${ }^{\mathrm{L}}$ Compact Mass Spectrometer with ESI ionization source (Advion, Ithaca, USA). The ${ }^{1} \mathrm{H}$ NMR spectrum was recorded using a $400 \mathrm{MHz}$ Avance Bruker spectrometer (Bruker Corporation, Billerica, USA). GC-FID analysis was conducted using a GC2010 (Shimadzu, Kyoto, JP) with a SolGelWAX column $(30 \mathrm{~m} \times 0.25 \mathrm{~mm} \times 0.25 \mu \mathrm{m}$; SGE Analytical Science, Melbourne, AU). One microliter sample was injected at $240{ }^{\circ} \mathrm{C}$ with the following column temperature program: $125{ }^{\circ} \mathrm{C} / 4.5 \mathrm{~min}-10{ }^{\circ} \mathrm{C} / \mathrm{min}-175{ }^{\circ} \mathrm{C} / 0 \mathrm{~min}-25{ }^{\circ} \mathrm{C} / \mathrm{min}-250$ ${ }^{\circ} \mathrm{C} / 9.5 \mathrm{~min}$. Raspberry ketone: $T_{\text {ret }}=16.4 \mathrm{~min}$, rhododendrol: $T_{\text {ret }}=17.2 \mathrm{~min}$.
For HPLC analysis, $50 \mu \mathrm{l}$ samples were extracted twice with $100 \mu$ l ethyl acetate. Combined organic phases were evaporated to dryness and resuspended in the corresponding HPLC solvent. Thereupon, samples were either analyzed by normal-phase HPLC (for separation of rhododendrol enantiomers) or reverse-phase HPLC (for analysis of rhododendrol glycosides). Normal-phase HPLC was performed on a VWR Hitachi LaChrom Elite system (VWR International, Radnor, USA) equipped with a Lux ${ }^{\circledR} 5 \mu$ m Cellulose- 1 column $(250 \times$ $4.6 \mathrm{~mm}$; Phenomenex Inc., Torrance, USA). Ten microliter injected sample were separated at $30{ }^{\circ} \mathrm{C}$ in $n$-hexane $/ i-\mathrm{PrOH}$ $(9: 1, \mathrm{v} / \mathrm{v})$ at $0.8 \mathrm{ml} / \mathrm{min}$ isocratic flow and detected via $\mathrm{UV}$ at $220 \mathrm{~nm}$. Reverse-phase HPLC was performed on a VWR Hitachi Chromaster system (VWR International, Radnor, USA) equipped with a Hypersil ODS $5 \mu \mathrm{m}(250 \times 4.6 \mathrm{~mm})$ column (Agilent Technologies, Santa Clara, US). Ten microliter injected sample were separated at $40{ }^{\circ} \mathrm{C}$ in $\mathrm{MeCN} / \mathrm{ddH}_{2} \mathrm{O}$ with $0.1 \%$ formic acid $(15: 85, \mathrm{v} / \mathrm{v})$ at $1 \mathrm{ml} /$ min isocratic flow and detected via UV at $200 \mathrm{~nm}$.

\section{Results}

\section{Investigation of different alcohol dehydrogenases for the oxidation of rhododendrol}

In view of the various starting material with different rhododendrol enantiomers available in nature, different recombinantly expressed alcohol dehydrogenases (ADHs) were investigated for the oxidation of a racemic mixture of $(R)$ - and $(S)$-rhododendrol to raspberry ketone. Out of the five investigated ADHs, enzymes converting either of the enantiomers of racemic rhododendrol could be identified (Table 1): the ADHs from Rhodococcus ruber (RR-ADH) and Equus caballus (ADH1E) both oxidized (S)-rhododendrol (Fig. 2a, b, S9 and S10), whereas ADHs from Lactobacillus brevis (LB-ADH), Lactobacillus kefir (LK-ADH), and Leifsonia sp. (LS-ADH) showed (R)-selectivity (Fig. 2c-e and Figure S11-13). The respective rhododendrol enantiomer was fully converted within two hours by ADH1E (Figure 2b), LB-ADH (Figure 2c) and LKADH (Figure 2d). With the same volume of LS-ADH lysate the oxidation proceeded considerably slower, full conversion of $(R)$-rhododendrol was only accomplished after $24 \mathrm{~h}$. After $8 \mathrm{~h}$ reaction time with the RR-ADH $9.3 \pm 0.4 \%,(S)$-rhododendrol remained unconverted.

By combining an $(S)$ - and an $(R)$-selective $\mathrm{ADH}$, such as ADH1E and LK-ADH, high conversion of both rhododendrol enantiomers was attained within $24 \mathrm{~h}$ resulting in $71.8 \pm 2.1 \%$ raspberry ketone (Fig. 2f and Figure S14). During all these experiments, a cofactor recycling was successfully achieved by an engineered NAD $(\mathrm{P}) \mathrm{H}$ oxidase from Streptococcus 
Table 1 Cofactor-dependency, enantioselectivity towards rhododendrol and conversion to raspberry ketone by the investigated ADHs in a certain reaction time (a maximum of 50 $\%$ conversion is theoretically possible)

\begin{tabular}{lllll}
\hline ADH & Cofactor & Enantioselectivity & Conversion [\%] & Reaction time [h] \\
\hline RR-ADH (Rhodococcus ruber) & $\mathrm{NAD}^{+}$ & $(S)$ & $38.4 \pm 1.4$ & 8 \\
ADH1E (Equus caballus) & $\mathrm{NAD}^{+}$ & $(S)$ & $43.8 \pm 1.0$ & 2 \\
LB-ADH (Lactobacillus brevis) & $\mathrm{NADP}^{+}$ & $(R)$ & $51.4 \pm 1.3$ & 2 \\
LK-ADH (Lactobacillus kefir) & $\mathrm{NADP}^{+}$ & $(R)$ & $43.7 \pm 0.9$ & 2 \\
LS-ADH (Leifsonia sp.) & $\mathrm{NAD}^{+}$ & $(R)$ & $39.0 \pm 0.4$ & 24 \\
\hline
\end{tabular}

mutans (SmNOX) that oxidizes both NADH and NADPH with similar efficiency (Petschacher et al. 2014).

\section{Two-step biocatalytic cascade for raspberry ketone production}

Following, these rhododendrol converting ADHs were aimed to be applied as a second step in a biocatalytic cascade with rhododendrol glycosides as starting material (Figs. 1 and 3). In this case, a 1:1 mixture of mainly arabinosyl- and apiosylrhododendrin originating from Betula pendula was used.

The first reaction step, the hydrolysis of the glycosidic bond of the rhododendrol glycosides to release the raspberry ketone precursor rhododendrol, was accomplished by a commercial $\beta$-glucosidase from almonds (ALM) showing highest activity at $\mathrm{pH} 5.5$ and at least $40{ }^{\circ} \mathrm{C}$ (Becker et al. 2020). The influence of the substrate load was investigated in concentrations up to $10 \mathrm{mg} / \mathrm{ml}(\sim 21.7 \mathrm{mM})$ resulting in a conversion of $80 \pm 1 \%$ within only $2 \mathrm{~h}$ using $1 \mathrm{mg} / \mathrm{ml}(\sim 7.4$ $\mu \mathrm{M})$ ALM in small-scale reactions (Figures S15-S17). The formed rhododendrol predominantly showed $(R)$-configuration (99.1\% HPLC peak area; Figure S18).

After these optimizations of the first reaction step, a twostep biocatalytic cascade with $150 \mathrm{mg}$ of the rhododendrol glycoside mixture was conducted (Fig. 3). The hydrolysis of the rhododendrol glycosides $(10 \mathrm{mg} / \mathrm{ml})$ by ALM $(1 \mathrm{mg} / \mathrm{ml})$ showed $82 \pm 4 \%$ conversion after $24 \mathrm{~h}$ (Fig. 3 and Figure S19). As the hydrolysis of the rhododendrol glycosides predominantly resulted in $(R)$-rhododendrol, the $(R)$-specific LBADH $(5.7 \mathrm{U} / \mathrm{ml})$ was applied in the second reaction step of the cascade together with the cofactor-recycling enzyme SmNOX. After $24 \mathrm{~h}, 94 \pm 1 \%$ of the rhododendrol was converted while, additionally, remaining rhododendrol glycosides from the first reaction step were even further hydrolyzed during this second reaction step (Figure S20). In total, $55 \mathrm{mg}$
Fig. 2 Time course of the oxidation of racemic rhododendrol (1 $\mathrm{mM})$ to raspberry ketone catalyzed by a RR-ADH $(8.0 \mathrm{U} / \mathrm{ml})$, b ADH1E (57 U/l), c LB-ADH (6.9 U/ml), d LK-ADH (3.0 U/ml), e LS-ADH (36.1 U/l), and $\mathbf{f}$ a combination of ADH1E (28.5 U/l) and LK-ADH (6 U/ml)
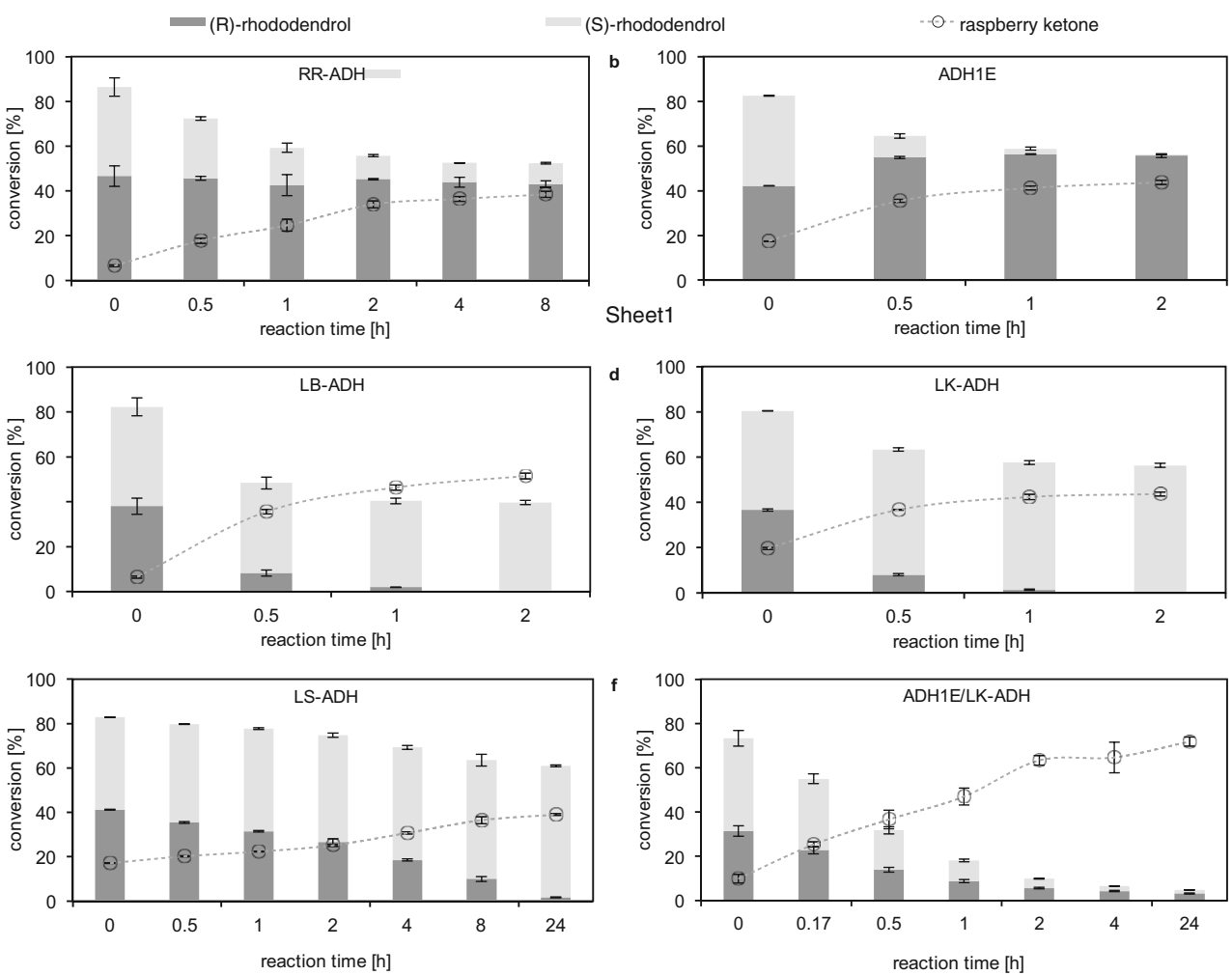
Fig. 3 Schematic depiction of the biocatalytic cascade for raspberry ketone production including achieved conversions for each reaction step

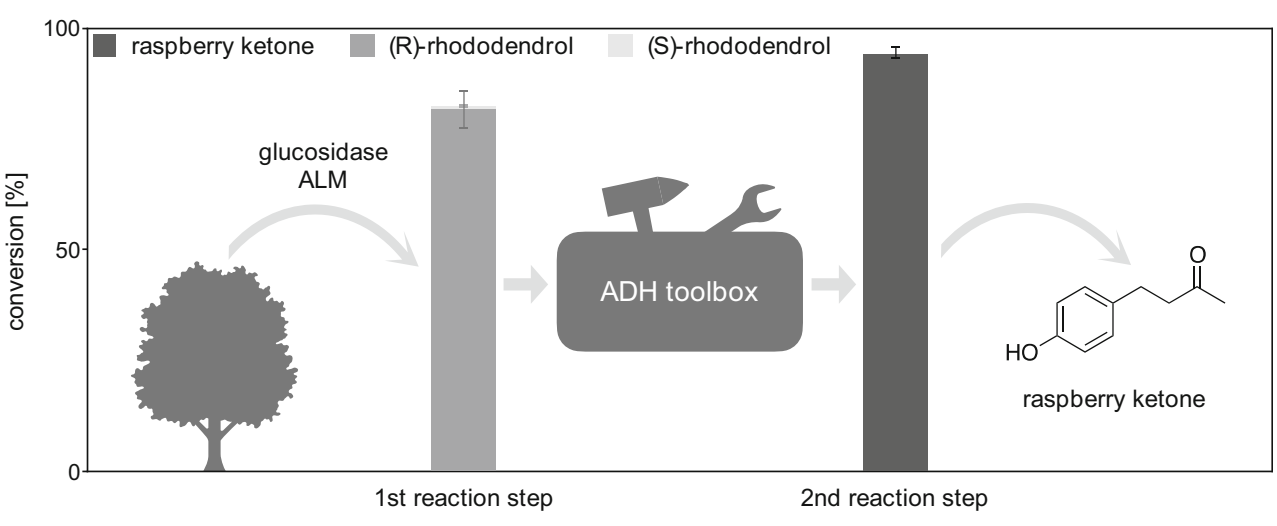

raspberry ketone $\left(\mathrm{m} / \mathrm{z} 163[\mathrm{M}-\mathrm{H}]^{-}\right)$were isolated by extraction in a purity of approximately $90 \%$ (determined via NMR analysis, Figures S1 and S2, Table S1; $91 \%$ purity according to GC analysis, Figure S23) starting from $150 \mathrm{mg}$ raw material. This corresponds to an isolated yield of approximately $93 \%$.

\section{Discussion}

\section{Investigation of different alcohol dehydrogenases for the oxidation of rhododendrol}

Five ADHs that convert either $(R)$ - or $(S)$-rhododendrol are presented in this study. These ADHs showed the same selectivities concerning rhododendrol as described in literature for similar substrates (Kosjek et al. 2004; Inoue et al. 2005a; Weckbecker and Hummel 2006; Leuchs and Greiner 2011; Quaglia et al. 2012). All ADHs are compatible in terms of $\mathrm{pH}$ range (Figure S24) being preferably used between $\mathrm{pH} 9$ and 10 for oxidation reactions (Kosjek et al. 2004; Inoue et al. 2005a; Quaglia et al. 2012). Moreover, reactions are ideally conducted between 25 and $40{ }^{\circ} \mathrm{C}$.

Depending on the optical purity of the intermediate rhododendrol, one or two suitable ADHs can be chosen from the herein presented toolbox. We demonstrated this with a racemic mixture of rhododendrol that was converted to 71.8 $\pm 2.1 \%$ raspberry ketone by the combinatorial use of an $(R)$ and an $(S)$-selective ADH (LK-ADH and ADH1E). This conversion attained by using these two ADHs with contrary selectivity clearly outperforms the process presented in literature where only one enantiomer of racemic rhododendrol was converted yielding $52 \%$ raspberry ketone (Kosjek et al. 2003).

The challenge concerning the recycling of expensive cofactors was elegantly solved by applying the engineered water-forming oxidase SmNOX that is capable of oxidizing both NADH and NADPH with similar efficiency (Petschacher et al. 2014). This proved to be particularly beneficial as the enzymes used in this study are dependent on different cofactors: $(R)$-selective $\mathrm{LK}$ - and $\mathrm{LB}-\mathrm{ADH}$ use $\mathrm{NADP}^{+}$, whereas the remaining $\mathrm{ADHs}$ require $\mathrm{NAD}^{+}$for catalysis (Table 1).

\section{Two-step biocatalytic cascade for raspberry ketone production}

A 1:1 mixture of arabinosyl- and apiosylrhododendrin originally derived from Betula pendula was utilized as a starting material. The commercially available glucosidase ALM showed efficient conversion of this rhododendrol glycoside mixture to predominantly $(R)$-rhododendrol. Compared to literature this finding confirms that the $(R)$-enantiomer of rhododendrol dominates in rhododendrol glycoside material originating from Betula pendula (Šmite et al. 1993; Liimatainen et al. 2008; Liimatainen et al. 2012).

Hence, for the two-step biocatalytic cascade in a preparative scale using $150 \mathrm{mg}$ rhododendrol glycosides, the $(R)$-selective LB-ADH was chosen from the toolbox for the second reaction step in view of the optical purity of the starting material. The enzymes LK-ADH and LS-ADH would have been suitable as well. This cascade reaction with the glucosidase ALM and the alcohol dehydrogenase LB-ADH yielded approximately $93 \%$ isolated raspberry ketone which slightly surpasses the result achieved by Falconnier et al. 1999 who used a Pichia strain showing only activity towards $(R)$-rhododendrol. However, as they started from rhododendrol glycosides from $B$. alba where the $(R)$-rhododendrol dominates as well with $95 \%$ (Falconnier et al. 1999), they could report a similar high conversion to $82.1 \%$ raspberry ketone. In contrast to this, with our ADH toolbox including SmNOX for easy cofactor regeneration, we are able to convert a variety of starting materials with high yields as we can not only use rhododendrol glycosides with high proportions of $(R)$-rhododendrol but also $(S)$-rhododendrol by selecting different ADHs from our toolbox. Even the conversion of a mixture of starting materials from different natural sources without prior analysis of the optical purity would be possible by utilizing the ADH toolbox.

With this study, we lay a solid foundation for future process optimization studies where parameters like substrate load, the ratios of the applied ADHs, mass transfer, or downstream processing may be optimized to achieve an economically efficient scale-up procedure. It may also be considered to expand the toolbox with non-stereoselective ADHs, e.g., by 
protein engineering (Musa et al. 2015). Besides, the ADH toolbox along with the universal cofactor-recycling enzyme SmNOX might potentially also be used for the conversion of similar enantiomeric substrates, especially in view of the broad substrate spectra of the ADHs (Inoue et al. 2005b; Weckbecker and Hummel 2006; Leuchs and Greiner 2011; Hollmann et al. 2012; Rodríguez et al. 2014; Itoh 2014). Finally, this strategy benefits from being GMO-free compared to known raspberry production pathways in engineered microorganisms (e.g., Schloesser and Lambert 2018) resulting in a higher acceptance at the food market.

Supplementary Information The online version contains supplementary material available at https://doi.org/10.1007/s00253-021-11332-9.

Acknowledgements The authors would also like to thank Ina Menyes for supporting the HPLC analysis.

Availability of data and material The datasets generated during and/or analyzed during the current study are available from the corresponding author on reasonable request.

Code availability Not applicable.

Author contribution UTB and LMK conceived the research project. AB designed and conducted experiments supported by DB, WK, and KS. WK and KS purified rhododendrol glycosides and contributed racrhododendrol. KS conducted and analyzed the NMR measurement. AB analyzed the data. $\mathrm{AB}$ wrote the manuscript to which all authors contributed. All authors read and approved the manuscript.

Funding Open access funding enabled and organized by Projekt DEAL. This work was supported by the Bundesministerium für Bildung und Forschung (Grant No. 031B0575).

\section{Declarations}

Ethics approval Not applicable. This article does not contain any studies with human participants or animals performed by any of the authors.

Consent to participate Not applicable.

\section{Consent for publication Not applicable.}

Conflicts of interest LMK, KS, and WK are employees of AnalytiCon Discovery GmbH (Potsdam, DE), a company active in the field of natural product research and development.

Open Access This article is licensed under a Creative Commons Attribution 4.0 International License, which permits use, sharing, adaptation, distribution and reproduction in any medium or format, as long as you give appropriate credit to the original author(s) and the source, provide a link to the Creative Commons licence, and indicate if changes were made. The images or other third party material in this article are included in the article's Creative Commons licence, unless indicated otherwise in a credit line to the material. If material is not included in the article's Creative Commons licence and your intended use is not permitted by statutory regulation or exceeds the permitted use, you will need to obtain permission directly from the copyright holder. To view a copy of this licence, visit http://creativecommons.org/licenses/by/4.0/.

\section{References}

Becker A, Böttcher D, Katzer W, Siems K, Müller-Kuhrt L, Bornscheuer UT (2020) A biocatalytic cascade reaction to access a valuable longchain $\omega$-hydroxy fatty acid. ChemCatChem 12:4084-4089. https:// doi.org/10.1002/cctc.202000745

Beekwilder J, van der Meer IM, Sibbesen O, Broekgaarden M, Qvist I, Mikkelsen JD, Hall RD (2007) Microbial production of natural raspberry ketone. Biotechnol J 2:1270-1279. https://doi.org/10. 1002/biot.200700076

Cankar K, Beekwilder MJ, Bosch HJ, van der Schaft PH, Weemen WMJ (2019) Production of a flavour compound in a host cell. WO2019097049A1

Chang C, Liu B (2021) Efficient bioconversion of raspberry ketone in Escherichia coli using fatty acids feedstocks. Microb Cell Factories 20:68. https://doi.org/10.1186/s12934-021-01551-0

Deckers M, Deforce D, Fraiture M-A, Roosens NHC (2020) Genetically modified micro-organisms for industrial food enzyme production: an overview. Foods 9:326-345. https://doi.org/10.3390/ foods 9030326

Deifel A (1989) 4-(4-Hydroxyphenyl)-2-butanon - Himbeerketon Übersicht über natürliches Vorkommen und Biogenese. Z Lebensm Unters Forsch 188:330-332. https://doi.org/10.1007/ BF01352391

Dumont B, Hugueny P, Belin J-M (1996) Preparation of raspberry-like ketones by bioconversion. EP0707072A1

European Parliament (2003) Regulation (EC) No 1829/2003 of the European Parliament and of the Council of 22 September 2003 on genetically modified food and feed

European Parliament (2008) Regulation (EC) No 1334/2008 of the European Parliament and of the Council on flavourings and certain food ingredients with flavouring properties for use in and on foods and amending Council Regulation (EEC) No 1601/91, Regulations (EC) No 2232/96 and (EC) No 110/2008 and Directive 2000/13/EC

Falconnier B, Godard N, Attard L, Girard P (1999) Raspberry ketone bioconversion. WO1999049069A1

Farwick AM, Desfougeres T, Pignede G, Roussel A, Mouly I, Morvan B (2019) Production of frambinone by a recombinant fungal microorganism. US2019030930A1

Fouad D, Badr A, Attia HA (2019) Hepatoprotective activity of raspberry ketone is mediated via inhibition of the NF- $\mathrm{KB} / \mathrm{TNF}-\alpha$ /caspase axis and mitochondrial apoptosis in chemically induced acute liver injury. Toxicol Res 8:663-676. https://doi.org/10.1039/c9tx00068b

Fronza G, Fuganti C, Pedrocchi-Fantoni G, Serra S, Zucchi G, Fauhl C, Guillou C, Reniero F (1999) Stable isotope characterization of raspberry ketone extracted from Taxus baccata and obtained by oxidation of the accompanying alcohol (betuligenol). J Agric Food Chem 47:1150-1155. https://doi.org/10.1021/jf980717u

Hamdy SM, El-Khayat Z, Farrag AR, Sayed ON, El-Sayed MM, Massoud D (2020) Hepatoprotective effect of raspberry ketone and white tea against acrylamide-induced toxicity in rats. Drug Chem Toxicol:1-9. https://doi.org/10.1080/01480545.2020. 1772279

Harada N, Okajima K, Narimatsu N, Kurihara H, Nakagata N (2008) Effect of topical application of raspberry ketone on dermal production of insulin-like growth factor-I in mice and on hair growth and skin elasticity in humans. Growth Hormon IGF Res 18:335-344. https://doi.org/10.1016/j.ghir.2008.01.005

Hollmann F, Bühler K, Bühler B (2012) Oxidation of alcohols, aldehydes, and acids. In: Drauz K, Gröger H, May O (eds) Enzyme catalysis in organic synthesis, 3rd edn, vol 1. Wiley, Weinheim, pp 1325-1437

Inoue K, Makino Y, Itoh N (2005a) Purification and characterization of a novel alcohol dehydrogenase from Leifsonia sp. strain S749: a promising biocatalyst for an asymmetric hydrogen transfer 
bioreduction. Appl Environ Microbiol 71:3633-3641. https://doi. org/10.1128/AEM.71.7.3633-3641.2005

Inoue $\mathrm{K}$, Makino Y, Itoh N (2005b) Production of $(R)$-chiral alcohols by a hydrogen-transfer bioreduction with NADH-dependent Leifsonia alcohol dehydrogenase (LSADH). Tetrahedron Asymmetry 16: 2539-2549. https://doi.org/10.1016/j.tetasy.2005.06.036

Itoh N (2014) Use of the anti-Prelog stereospecific alcohol dehydrogenase from Leifsonia and Pseudomonas for producing chiral alcohols. Appl Microbiol Biotechnol 98:3889-3904. https://doi.org/10. 1007/s00253-014-5619-5

Khan V, Sharma S, Bhandari U, Ali SM, Haque SE (2018) Raspberry ketone protects against isoproterenol-induced myocardial infarction in rats. Life Sci 194:205-212. https://doi.org/10.1016/j.lfs.2017.12. 013

Kim M, Baek HS, Lee M, Park H, Shin SS, Choi DW, Lim K-M (2016) Rhododenol and raspberry ketone impair the normal proliferation of melanocytes through reactive oxygen species-dependent activation of GADD45. Toxicol in Vitro 32:339-346. https://doi.org/10.1016/ j.tiv.2016.02.003

Kosjek B, Stampfer W, van Deursen R, Faber K, Kroutil W (2003) Efficient production of raspberry ketone via 'green' biocatalytic oxidation. Tetrahedron 59:9517-9521. https://doi.org/10.1016/j.tet. 2003.10.019

Kosjek B, Stampfer W, Pogorevc M, Goessler W, Faber K, Kroutil W (2004) Purification and characterization of a chemotolerant alcohol dehydrogenase applicable to coupled redox reactions. Biotechnol Bioeng 86:55-62. https://doi.org/10.1002/bit.20004

Larsen M, Poll L (1990) Odour thresholds of some important aroma compounds in raspberries. Z Lebensm Unters Forch 191:129-131. https://doi.org/10.1007/BF01202638

Larsen M, Poll L, Callesen O, Lewis M (1991) Relations between the content of aroma compounds and the sensory evaluation of 10 raspberry varieties (Rubus idaeus L). Acta Agric Scand 41:447-454. https://doi.org/10.1080/00015129109439927

Lee D, Lloyd NDR, Pretorius IS, Borneman AR (2016) Heterologous production of raspberry ketone in the wine yeast Saccharomyces cerevisiae via pathway engineering and synthetic enzyme fusion. Microb Cell Factories 15:49. https://doi.org/10.1186/s12934-0160446-2

Leuchs S, Greiner L (2011) Alcohol dehydrogenase from Lactobacillus brevis: a versatile robust catalyst for enantioselective transformations. Chem Biochem Eng Q 25:267-281 https://hrcak.srce.hr/ 69863

Liimatainen J, Sinkkonen J, Karonen M, Pihlaja K (2008) Two new phenylbutanoids from inner bark of Betula pendula. Magn Reson Chem 46:195-198. https://doi.org/10.1002/mrc.2163

Liimatainen J, Karonen M, Sinkkonen J, Helander M, Salminen J-P (2012) Characterization of phenolic compounds from inner bark of Betula pendula. Holzforschung 66:171-181. https://doi.org/10. 1515/HF.2011.146

Malik T, Rawat S (2021) Biotechnological interventions for production of flavour and fragrance. In: Venkatramanan V, Shah S, Prasad R (eds) Sustainable bioeconomy, pathways to sustainable development goals, 1st edn. Springer, Singapore, pp 142-157

Metcalf RL, Mitchell WC, Metcalf ER (1983) Olfactory receptors in the melon fly Dacus cucurbitae and the oriental fruit fly Dacus dorsalis. Proc Natl Acad Sci U S A 80:3143-3147. https://doi.org/10.1073/ pnas.80.11.3143

Milke L, Mutz M, Marienhagen J (2020) Synthesis of the character impact compound raspberry ketone and additional flavoring phenylbutanoids of biotechnological interest with Corynebacterium glutamicum. Microb Cell Factories 19:92. https://doi.org/10.1186/s12934-020-01351-y

Mir TM, Ma G, Ali Z, Khan IA, Ashfaq MK (2019) Effect of raspberry ketone on normal, obese and health-compromised obese mice: a preliminary study. J Diet Suppl 18:1-16. https://doi.org/10.1080/ 19390211.2019.1674996

Mohamed MT, Zaitone SA, Ahmed A, Mehanna ET, El-Sayed NM (2020) Raspberry ketones attenuate cyclophosphamide-induced pulmonary toxicity in mice through inhibition of oxidative stress and NF-KB pathway. Antioxidants 9:1168-1181. https://doi.org/10. 3390/antiox9111168

Morimoto C, Satoh Y, Hara M, Inoue S, Tsujita T, Okuda H (2005) Antiobese action of raspberry ketone. Life Sci 77:194-204. https://doi. org/10.1016/j.lfs.2004.12.029

Musa MM, Patel JM, Nealon CM, Kim CS, Phillips RS, Karume I (2015) Thermoanaerobacter ethanolicus secondary alcohol dehydrogenase mutants with improved racemization activity. J Mol Catal B Enzym 115:155-159. https://doi.org/10.1016/j.molcatb.2015.02.012

Park KS (2015) Raspberry ketone, a naturally occurring phenolic compound, inhibits adipogenic and lipogenic gene expression in 3T3-L1 adipocytes. Pharm Biol 53:870-875. https://doi.org/10.3109/ 13880209.2014.946059

Parmar VS, Tripathi SC (1991) Absolute configuration of epirhododendrin and (-)-rhododendrol [-(-)-betuligenol] and X-ray crystal and molecular structure of rhododendrin [=betuloside], a hepatoprotective constituent of Taxus baccata. J Chem Soc Perkin Trans 1(11):2687-2690. https://doi.org/10.1039/P19910002687

Paulino BN (2021) Recent advances in the microbial and enzymatic production of aroma compounds. Curr Opin Food Sci 37:98-106. https://doi.org/10.1016/j.cofs.2020.09.010

Perez RL (1983) Gas chromatographic determination of raspberry ketone and malathion in insect bait concentrates. J Chromatogr A 259:176180. https://doi.org/10.1016/S0021-9673(01)87993-0

Petschacher B, Staunig N, Müller M, Schürmann M, Mink D, Wildeman SD, Gruber K, Glieder A (2014) Cofactor specificity engineering of Streptococcus mutans $\mathrm{NADH}$ oxidase 2 for $\mathrm{NAD}(\mathrm{P})^{+}$regeneration in biocatalytic oxidations. Comput Struct Biotechnol J 9: e201402005. https://doi.org/10.5936/csbj.201402005

Quaglia D, Irwin JA, Paradisi F (2012) Horse liver alcohol dehydrogenase: new perspectives for an old enzyme. Mol Biotechnol 52:244 250. https://doi.org/10.1007/s12033-012-9542-7

Rodríguez C, Borzęcka W, Sattler JH, Kroutil W, Lavandera I, Gotor V (2014) Steric vs. electronic effects in the Lactobacillus brevis ADHcatalyzed bioreduction of ketones. Org Biomol Chem 12:673-681. https://doi.org/10.1039/C3OB42057D

Santamour FS, Lundgren LN (1997) Rhododendrin in Betula: a reappraisal. Biochem Syst Ecol 25:335-341. https://doi.org/10.1016/ S0305-1978(97)83745-3

Santamour FS, Vettel HE (1978) The distribution of rhododendrin in birch (Betula) species. Biochem Syst Ecol 6:107-108. https://doi. org/10.1016/0305-1978(78)90034-0

Sattler JH, Fuchs M, Mutti FG, Grischek B, Engel P, Pfeffer J, Woodley JM, Kroutil W (2014) Introducing an in situ capping strategy in systems biocatalysis to access 6-aminohexanoic acid. Angew Chem 126:14377-14381. https://doi.org/10.1002/ange.201409227

Schloesser T, Lambert F (2018) Strain of microorganisms and method for the fermentative production of raspberry ketone. WO2018210432A1

Šmite E, Lundgren LN, Andersson R (1993) Arylbutanoid and diarylheptanoid glycosides from inner bark of Betula pendula. Phytochemistry 32:365-369. https://doi.org/10.1016/S00319422(00)94995-1

Thieme H, Walewska E, Winkler HJ (1969) Isolierung von Rhododendrin aus Bergenia-Arten [Isolation of rhododendrine from Bergenia-varieties]. Pharmazie 24:648

Tsai Y-C, Yang B-C, Peng W-H, Lee Y-M, Yen M-H, Cheng P-Y (2017) Heme oxygenase-1 mediates anti-adipogenesis effect of raspberry ketone in 3T3-L1 cells. Phytomedicine 31:11-17. https://doi.org/10. 1016/j.phymed.2017.05.005 
Wang C, Zheng P, Chen P (2019) Construction of synthetic pathways for raspberry ketone production in engineered Escherichia coli. Appl Microbiol Biotechnol 103:3715-3725. https://doi.org/10.1007/ s00253-019-09748-5

Weckbecker A, Hummel W (2006) Cloning, expression, and characterization of an $(R)$-specific alcohol dehydrogenase from Lactobacillus kefir. Biocatal Biotransformation 24:380-389. https://doi.org/10. 1080/10242420600893827

Yang B, Zheng P, Wu D, Chen P (2021) Efficient biosynthesis of raspberry ketone by engineered Escherichia coli coexpressing zingerone synthase and glucose dehydrogenase. J Agric Food Chem 69:25492556. https://doi.org/10.1021/acs.jafc.0c07697

Zhao D, Yuan B, Kshatriya D, Polyak A, Simon J, Bello N, Wu Q (2019) Bioavailability and metabolism of raspberry ketone with potential implications for obesity prevention (OR34-05-19). Curr Dev Nutr 3: 503-504. https://doi.org/10.1093/cdn/nzz031.OR34-05-19

Publisher's note Springer Nature remains neutral with regard to jurisdictional claims in published maps and institutional affiliations. 